\title{
Khazanah Passenger's Utterence Train Department of Malang — Bandung (Sosiopragmatic Study)
}

\author{
Sofia Eka Kurniasari \\ IKIP Budi Utomo \\ sofiaeka92@gmail.com \\ Vrestanti Novalia Santosa \\ IKIP Budi Utomo \\ vrestanti18@gmail.com
}

\begin{abstract}
This research aims to (1) describe code-switching utterences of train passenger's MalangBandung, (2)describe the meaning of utterences of train passenger's Malang-Bandung, (3) describe the effect of utterances of train passenger's Malang-Bandung. This type of the research is a descriptive qualitative research. The research methodeused case study that lead to phenomenology approach. The subjects of of the research are the train passengers with form of utterences. The technique used of collecting data are SBLC, record, notes, and documentation technique.The instrument are notes, recording devices containing audio, visual, and audio-visual. The result of the research is a khazanah of utterences of train pasengers Malang-Bandung route with some factors that being background of code-switching occurred. This research uses siciopragmatic in analyzing the data to find the meaning of the utterence on the use of language in certtain cultural societies and social conditions. The result of the research included (1) the speech form of code-switching the train passengger's for Malang-Bandung that was part of the intern and ekstern code, (2) the official meaning utterences code-switching of train pasengger's MalangBandung, and (3) factors that affected the code-switching of train passengger's Malang-Bandung.
\end{abstract}

Keywords: khazanah; passenger's utterence; code switching; sociopragmatics.

\section{PENDAHULUAN}

Alat transportasi merupakan sebuah alat yang dapat membantu dalam memindahkan suatu barang atau manusia dari satu tempat ke tempat lain, hal ini digunakan untuk mempermudah aktivitas sehari-hari. Indonesia memiliki beragam alat transportasi baik transportasi tradisional maupun modern. Kehadiran alat transportasi menjadi sangat penting dalam proses keberlangsungan hidup manusia. Dalam hal ini alat transportasi memilik tiga jenis golongan, yaitu transportasi darat, transportasi laut, dan transportasi udara.

Salah satu alat transportasi darat yang menggunakan mesin uap adalah kereta api. Kereta api merupakan alat transportasi andalan masyarakat Indonesia baik dari kalangan bawah, menengah hingga atas.
Kereta api menjadi primadona masyarakat Indonesia dalam melakukan berbagai macam tujuan perjalanan. Peningkatan frekuensi pengguna jasa transportasi kereta api menyebabkan terjadinya beragam proses interaksi antarpenumpang. Dalam peristiwa komunikasi lisan antarpenumpang melakukan berbagai komunikasi dalam peristiwa yang berbeda dan untuk tujuan serta kepentingan yang berbeda pula. Peristiwa tutur tersebut dipengaruhi oleh konteks yang menyertainya, karena hakikatnya manusia memerlukan hubungan timbal balik dengan individu lainnya dalam kehidupan seharihari.

Hubungan timbal balik tersebut erat kaitannya dengan bahasa. Hal ini dikarenakan bahwa setiap manusia tidak bisa atau sulit sekali hidup tanpa bahasa. Bahasa 
merupakan satu di antara karakter alami manusia. Bahasa dapat dikelompokkan menjadi dua yaitu bahasa verbal dan bahasa nonverbal. Dalam perkembangannya di masyarakat, bahasa mengalami perkembangan karena bahasa bersifat dinamis. Oleh karena itu, dalam menggunakan bahasa pada saat bertutur sebaiknya masyarakat perlu memperhatikan konteks yang mengikutinya.

Masyarakat Indonesia terkenal dengan kemajemukan yang multikultural dan multilingual. Situasi kebahasaan penumpang kereta api jurusan Malang-Bandung diwarnai dengan pemakaian bahasa daerah dan bahasa Indonesia dengan segala kemungkinan pemakaian bahasa daerah lain dan bahasa asing. Menurut Alwi, dkk., (2010:5) mengatakan bahwa ragam bahasa menurut sikap penutur mencakup sejumlah corak bahasa Indonesia yang masing-masing pada dasarnya tersedia bagi tiap pemakai bahasa.

Menurut Chaer dan Agustina (2014:84) mengatakan bahwa kontak bahasa dapat menimbulkan berbagai fenomena kebahasaan, seperti kedwibahasaan, diglosia, alih kode, interferensi, konvergensi, pergeseran bahasa, dan pemertahanan bahasa. Seseorang yang terlibat dengan penggunaan dua bahasa dan juga terlibat dengan dua budaya (dwibahasawan). Salah satu akibat dari kedwibahasaan adalah adanya tumpang tindih dari dua sistem bahasa yang dipakai atau digunakannya unsur-unsur dari bahasa yang satu pada pengguna bahasa yang lain yaitu adanya alih kode (code switching).

Dari sisi linguistik, pemakaian bahasa ini dapat dikaji dengan menggunakan kajian pragmatik. Berdasarkan hal tersebut, pragmatik mengkaji teks atau tuturan verbal dari yang paling sederhana hingga yang paling rumit, berdasarkan konteks yang melibatkan teks atau tuturan itu sendiri serta situasi dan kondisi yang ada di luar teks atau tuturan, termasuk siapa penutur dan mitra tutur dalam berkomunikasi. Beragamnya peristiwa tutur berupa alih kode yang terjadi pada penumpang kereta api jurusan MalangBandung dengan berbagai latar belakang yang dapat memengaruhi munculnya khazanah tuturan di antara penumpang.

Munculnya berbagai fenomena kebahasaan antar penumpang kereta api dapat menimbulkan peralihan pemakaian bahasa yang disebabkan oleh berubahnya situasi dalam peristiwa tutur. Sehubungan dengan hakikat bahasa yang heterogen, pragmatik bisa digabungkan dengan disiplin ilmu linguistik lainnya yaitu salah satunya sosiolinguistik. Berdasarkan hal tersebut, peneliti tertarik untuk meneliti khazanah tuturan berupa alih kode yang terjadi pada tuturan penumpang kereta api jurusan Malang-Bandung dengan menggunakan kajian sosiopragmatik.

Penelitian yang relevan, yaitu (1) Hasil penelitian Aris Munandar pada tahun 2018 dalam bentuk skripsi Universitas Negeri Makassar yang berjudul Alih Kode dan Campur Kode Dalam Interaksi Masyarakat Terminal Mallengkeri Kota Makassar, (2) Hasil penelitian Diyah Atiek Mustikawati pada tahun 2015 dalam bentuk jurnal dari Universitas Muhammadiyah Ponorogo yang berjudul Alih Kode dan Campur Kode Antara Penjual dan Pembeli (Analisis Pembelajaran Berbahasa Melalui Studi Sosiolinguistik), dan (3) Hasil penelitian Wa Ode Nurjamily pada tahun 2015 dalam bentuk jurnal yang berjudul Kesantunan Berbahasa Indonesia dalam Lingkungan Keluarga (Kajian Sosiopragmatik).

Berdasarkan penelitian yang diuraikan, maka penelitian ini memiliki tujuan, yaitu (1) mendeskripsikan wujud tuturan alih kode penumpang kereta api jurusan MalangBandung,(2) mendeskripsikan makna tuturan alih kode penumpang kereta api jurusan Malang-Bandung, dan (3) mendeskripsikan 
pengaruh tuturan penumpang kereta api jurusan Malang — Bandung.

\section{METODE}

Jenis penelitian yang digunakan adalah penelitian kualitatif bersifat deskriptif dengan tujuan untuk mendapatkan deskripsi objektif tentang khazanah tuturan penumpang kereta api jurusan Malang-Bandung. Penelitian ini menggunakan pendekatan studi kasus yang mengarah pada ranah fenomenologi yang merupakan sebuah pendekatan yang mengizinkan peneliti menerapkan dan mengaplikasikan kemampuan subjektivitas dan interpersonalnya dalam proses penelitian eksploratori.

Subjek penelitian dalam penelitian ini adalah penumpang kereta api jurusan MalangBandung dengan bentuk kajian berupa tuturan. Adapun waktu yang digunakan untuk mengumpulkan data dalam penelitian ini, yaitu selama tiga bulan pada bulan JanuariMaret 2020. Lokasi penelitian ini dilakukan di KA Malabar dan Mutiara Selatan kelas ekonomi jurusan Malang-Bandung.

Teknik pengumpulan data dalam penelitian ini, yaitu (1) teknik SBLC (Simak Bebas Libat Cakap), (2) teknik rekam, (3) teknik catat, dan (4) teknik dokumentasi.
Instrumen penelitian merupakan alat bantu bagi peneliti dalam mengumpulkan data (Arikunto, 2007:134). Dalam penelitian ini instrumen penelitian yang digunakan, yaitu (1) lembar catatan, (2) alat perekam, dan (3) korpus data. Analisis data dalam penelitian ini dimulai dari mengumpulkan dan mempersiapkan data berupa tuturan penumpang KA Malabar dan Mutiara Selatan jurusan Malang-Bandung, mengklasifikasi data berdasarkan karakteristik penelitian, yaitu alih kode (code switching), dan menganalisis data berdasarkan landasan teori yang digunakan oleh peneliti, yaitu kajian sosiopragmatik.

\section{HASIL DAN PEMBAHASAN}

Penelitian ini mendeskripsikan wujud tuturan alih kode, makna tuturan alih kode, dan pengaruh atau faktor penyebab terjadinya alih kode dalam tuturan penumpang kereta api jurusan Malang-Bandung. Adapun hasil penelitian khazanah tuturan penumpang kereta api jurusan Malang-Bandung sebagai berikut:

\begin{tabular}{lll}
\hline No. $\quad$ Lokasi & \\
\hline 1. & KA & P1:Tapi itu kan perlu input KRS. \\
& P2:Yes, right, angkatan 2018 itu pokoknya.... \\
& P1: Do you have input KRS? (apakah kamu sudah input KRS?) \\
& P2: Not yet. (Masih belum.) \\
& P3: Mangan? (Makan?) \\
& P1: Beta hita mangan? (ayo kita makan?) \\
& P2: Makan? \\
& P1: Mangan au...(Aku mau makan) tapi aku nasinya ada tiga. \\
& P2:Ndak papa aku ayam aja. \\
& P3:'Halah, nggak kenyang itu jadinya. \\
& P1:Serius aku,...nih? \\
& P2:Makasi guys, eh ini nasi semua? eh salahlah, hehehe \\
& P1: Buka playlist JOOX! \\
& P2:EDM... \\
& P1:Halus nggak? (sambil melepas earphone temannya) \\
Malabar & P2:Nggak keluar. \\
& P1: Ageungan Volumena. (besarkan suaranya) \\
& P2: Pilih dulu. (hadir P3 menunjukkan ponselnya kepada P2)
\end{tabular}


P1: Bisa nggak?

$\mathrm{P} 2: \mathrm{Ha}$ ?

P1: Teu tiasa? (tidak bisa?) (sambil melepas earphone nya dan diberikan ke P2 kemudian bertukar earphone).

P2: Teu karetna? (nggak, ini karetnya) (sambil memasang earphone).

\section{KA P1: Rara. Sudah berapa hari ini, aku nggak bisa tidur.Terbayang bae terus wajah Mutiara dio. \\ Selatan P2: Sunnahan aja. \\ P1: Sudah, tapi malah wajahnya berasa muncul terus. \\ P2: Jangan-jangan kalian bakal berjodoh. \\ P1: Susah sih.}

\begin{tabular}{cll}
\hline 4. & KA & P1: Aku kok pusing ya? \\
& Palabar & Pau Fresh care? \\
& P1: He'em boleh. \\
& P3: Opo'o? (Kenapa) \\
& P2: Ngelu. (Pusing) \\
& P3: Yoh masuk angin kuwi, gawe kaos oblong. (Ya itu masuk angin, opakai kaos \\
& oblong). \\
& P2: Nggak cocok AC eh, hahaha... (Tidak cocok AC), hahaha \\
\hline 5. $\quad$ KA & P1: Haduh, punten...? \\
& P2: Ndak papa Mas, terima kasih ya. \\
& P1:Sama-sama. \\
& P2: Mas, tujuan mana? \\
& P1: Ambil semua bang, pasti habis. Hehehe \\
6. & P2: Pedes toh? \\
& P1: Yoi, level dua belas. \\
& P2:Siapin air mineral ya? \\
& P1: frezeer nya sekalian. Hehehe
\end{tabular}

\begin{tabular}{|c|c|c|}
\hline 7. & $\begin{array}{c}\text { KA } \\
\text { Malabar }\end{array}$ & $\begin{array}{l}\text { P1: Mau kemana, Neng? } \\
\text { P2: Mau ke Solo. } \\
\text { Ibu sendiri bade kamana? (Ibu sendiri mau kemana?) } \\
\text { P1: Madiun. } \\
\text { P2: Kulawargi di Madiun? (Keluarga di Madiun) } \\
\text { P1: Henteu, rerencangan kuliah bade nikah, janten kedah hadir. (tidak, ada sahabat } \\
\text { kuliah dulu mau menikah, jadi ya wajib hadir). }\end{array}$ \\
\hline 8. & $\begin{array}{c}\text { KA } \\
\text { Mutiara } \\
\text { Selatan }\end{array}$ & $\begin{array}{l}\text { P1: Kalau tidak dimulai dari sekarang, kapan lagi? } \\
\text { Properti itu menjanjikan loh, tuh banyak kan anak-anak PJ yang invest ke properti } \\
\text { sekarang. } \\
\text { Don't worry, everything is gonna be okay, from now and for 5-10 years } \\
\text { letter, emm... you will get the adventages this investment. (Jangan khawatir, semua } \\
\text { akan baik-baik saja, mulai dari sekarang dan 5-10 tahun kamu akan merasakan } \\
\text { keuntungan dari investasi ini). } \\
\text { P2: Are you sure? (Apa kamu yakin?) } \\
\text { P1: Come on, ngapain gua ngajak lu invest ini kalau nggak ada untungnya, } \\
\text { P2: Tunggu lah, gua masih ragu. } \\
\text { P1: Hidiiih lu mah... }\end{array}$ \\
\hline 9. & $\begin{array}{c}\text { KA } \\
\text { Mutiara } \\
\text { Selatan }\end{array}$ & $\begin{array}{l}\text { P1: Teh tawar hangat, Mbak. } \\
\text { P2: Berapa cup, Pak? } \\
\text { P3: Abdi nambut gunting? (Aku pinjam gunting?) } \\
\text { P2: Tuh aya dina sorog nu handap. (Itu ada di laci bawah) }\end{array}$ \\
\hline
\end{tabular}


Silahkan Pak, pesanan teh nya...

P1: Berapa, Mbak?

P2: Sepuluh ribu..

berikut:

Hasil penelitian dianalisis sebagai



\section{a) Alih Kode Intern}

\section{Bahasa Indonesia ke Bahasa Jawa}

Pada data (4) terjadi peristiwa alih kode intern di dalam kereta api Malabar.

(4)P1: Aku kok pusing ya?

P2: Mau Fresh care?

P1: He'em boleh.

P3: Opo'o? (Kenapa)

P2: Ngelu. (Pusing)

P3: Yoh masuk angin kuwi, gawe kaos

oblong. (Ya itu masuk angin, pakai kaos oblong).

P2: Nggak cocok AC eh, hahaha...

(Tidak cocok AC), hahaha.

Penggunaan peralihan kode ini ditunjukan pada kalimat Opo'o?, penambahan kata akhiran/sufiks "e $\underline{h}$ " pada kalimat Nggak cocok AC eh, hahaaa, menunjukkan ciri khas penambahan kata bahasa Jawa Malangan.

\section{Bahasa Indonesia ke Bahasa Sunda}

Pada data (10), terjadi peristiwa alih kode intern di dalam kereta api Malabar. Peritiwa

P2:Teteh,kemarin pendarahan hebat gitu, usia kandungannya sih baru tiga bulanan.

P1: Eta teh kandunganna lemah, fit, kudu leuwih dijaga. (Itu kandungannya lemah fit, harus lebih dijaga)

P2: Uhun, teteh pami tuang saalit. (iya, teteh kalau makan sedikit).

Penggunaan peralihan kode ini ditunjukkan dengan adanya kalimat Eta teh kandunganna lemah, fit, kudu leuwih dijaga.

\section{Bahasa Indonesia ke Bahasa Batak}

Pada data (1), terjadi peristiwa alih kode intern di dalam kereta api Malabar.

(1) P1: Mangan au...(Aku mau makan) tapi aku nasinya ada tiga.

P2:Ndak papa aku ayam aja. (Tida apaapa aku ayam saja)

P3:Halah, nggak kenyang itu jadinya.

P1: Serius aku,...nih?

P2:Makasi guys, eh ini nasi semua? eh salahlah, hehehe.

Penggunaan bahasa Indonesia pada tuturan P1 yang ditunjukkan dengan adanya kalimat Mangan au...(Aku mau makan) tapi aku nasinya ada tiga.

\section{Bahasa Indonesia ke Bahasa Palembang}

Pada data (3), terjadi peristiwa alih kode intern di dalam kereta api Mutiara Selatan.

(3) P1: Rara. Sudah berapa hari ini, aku nggak bisa tidur.Terbayang bae terus wajah dio.

P2: Sunnahan aja!

P1: Sudah, tapi malah wajahnya berasa muncul terus.

P2: Jangan-jangan kalian bakal berjodoh.

P1: Susah sih.

Pada data (3) di atas, pada awalnya P1 menggunakan ragam bahasa Indonesia yang ditunjukkan dengan adanya kalimat Rara. Sudah berapa hari ini, aku nggak bisa tidur kemudian beralih kode menggunakan bahasa Batak yang ditunjukkan dengan adanya kalimat Terbayang bae terus wajah dio.

\section{b) Alih Kode Ekstern}

Pada data (11), terjadi peristiwa alih kode ekstern di dalam kereta api Malabar.

(11) P1:... Nanti naik Logawa ya? Logawa. 
$\mathrm{P} 2: E e . .$. it just with for move the train from.. (Ee... hanya dengan pindah kereta dari...)

P3:New train? (Kereta baru?)

$\mathrm{P} 2$ :oh yeah."'(Oh iya...)

P3:Am 1 too late?(Apa saya terlambat?)

Pada data (11) di atas, pada awalnya P1 menggunakan bahasa Indonesia. Kehadiran P2 untuk berusaha membantu P1 dalam menerjemahkan tuturannya menggunakan bahasa Inggris terhadap P3 yang sedang membutuhkan informasi untuk transit berpindah menggunakan kereta tujuan baru, yang ditunjukkan dengan adanya kalimat Ee... it just with for move the train from. P3 diketahui sedang mengalami kesalahan tujuan saat naik kereta. Peralihan kode ekstern ini terjadi secara permanen. Namun penggunaan bahasa Inggris yang digunakan dalam tuturan tersebut tidak sesuai dengan gramatikal kebahasaan yang tepat. Tetapi makna dari isi tuturan tersebut bisa saling dipahami oleh P2 dan P3.

2) Makna Tuturan Alih Kode Penumpang

Kereta Api Jurusan Malang_Bandung

Makna dalam tuturan penumpang kereta api jurusan Malang-Bandung dapat terlihat pada uraian berikut.

a) Menegaskan atau Menjelaskan Sesuatu

Pada data (1), terjadi peristiwa alih kode di dalam Kereta Api Malabar.

(1)P1: Iya maksudnya dari jam delapan sampai jam berapa?

P3: Ha, jam delapan sampai jam tiga.

P1: Tapi itu kan perlu input KRS.

P2: Yes, right, angkatan 2018 itu pokoknya....

P1: Do you have input KRS? (apakah kamu sudah input KRS?)

P2: Not yet. (Masih belum.)

Terjadinya peristiwa alih kode pada data (1) ini ditandai dengan munculnya peralihan ragam bahasa Indonesia formal ke bahasa Inggris. Penggunaan ragam bahasa pertama adalah bahasa Indonesia formal, kemudian beralih kode menggunakan bahasa Inggris karena P1 bermaksud ingin menegaskan sesuatu perihal pernyataan mitra tutur yaitu P2 yang menggunakan bahasa Inggris. Penggunaan ragam bahasa Indonesia formal ini ditandai dengan struktur kalimat yang baku dan lengkap, sedangkan penggunaan bahasa Inggris ditunjukkan dengan adanya kalimat Do you have input KRS?.

\section{b) Mengakrabkan Diri}

Pada data (7), terjadi peristiwa alih kode intern di dalam kereta api Malabar.

(7) P1: Mau kemana, Neng?

P2: Mau ke Solo.

Ibu sendiri bade kamana? (Ibu sendiri mau kemana?)

P1: Madiun.

Terjadinya peristiwa alih kode intern pada data (7) ini ditandai dengan munculnya peralihan ragam bahasa Indonesia informal ke bahasa Sunda. Penggunaan ragam bahasa pertama adalah ragam bahasa Indonesia informal, kemudian beralih kode menggunakan bahasa Sunda yang ditunjukkan dengan adanya kalimat $\underline{I b u}$ sendiri bade kamana?, karena $\mathrm{P} 2$ bermaksud untuk tujuan mengakrabkan diri. Beralih kodenya P2 menggunakan bahasa Sunda karena P2 mengetahui logat P1 yang juga merupakan penutur bahasa Sunda.

c) Menawarkan Sesuatu

Pada data (1), terjadi peristiwa alih kode intern di dalam kereta api Malabar.

(1)P3: Mangan? (Makan?)

P1: Beta hita mangan? (ayo kita makan?)

P2: Makan?

P1: Mangan au...(Aku mau makan) tapi aku nasinya ada tiga.

P2: Ndak papa aku ayam aja.

P3:Halah, nggak kenyang itu jadinya.

P1:Serius aku,...nih?

P2:Makasi guys, eh ini nasi semua? eh salahlah, hehehe 
Terjadinya peristiwa alih kode intern pada data (1) ini ditandai dengan munculnya peralihan dari bahasa Batak ke rargam bahasa Indonesia informal. Penggunaan ragam bahasa pertama adalah bahasa Batak yang ditunjukkan dengan adanya kalimat Beta hita mangan?, kemudian beralih kode menggunakan ragam bahasa Indonesia informal untuk tujuan menawarkan makanan kepada P2\&P3.

\section{d) Memerintahkan Sesuatu}

Pada data (2), terjadi peristiwa alih kode intern di dalam kereta api Malabar.

(2)P1: Buka playlist JOOX!

$\mathrm{P} 2: \mathrm{EDM} \ldots$

P1:Halus nggak? (sambil melepas earphone temannya)

P2:Nggak keluar.

P1:Ageungan Volumena! (besarkan suaranya)

P2:Pilih dulu."(hadir P3 menunjukkan ponselnya kepada $\mathrm{P} 2$ )

P1:Bisa nggak?

$\mathrm{P} 2: \mathrm{Ha}$ ?

$\mathrm{P} 1: \mathrm{Teu}$ tiasa?(sambil melepas earphone nya dan diberikan ke P2 kemudian bertukar earphone).

P2:Teu karetna? (sambil memasang earphone).

Terjadinya peristiwa alih kode intern pada data (2) ini ditandai dengan munculnya peralihan ragam bahasa Indonesia informal ke bahasa Sunda. P1 beralih kode menggunakan bahasa Sunda yang ditunjukkan dengan adanya kalimat Ageungan Volumena! yang bertujuan untuk memerintahkan P2 untuk membesarkan volume musik yang da di ponsel genggamnya. Dalam tuturan tersebut terdapat kata $E D M$ yang dimaksudkan adalah genre musik.

\section{e) Meyakinkan Sesuatu}

Pada data (8), terjadi peristiwa alih kode intern dan ekstern di dalam kereta api Mutiara Selatan.
(8)P1: Kalau tidak dimulai dari sekarang, kapan lagi?

Properti itu menjanjikan loh, tuh banyak kan anak-anak PJ yang invest ke properti sekarang.

Don't worry, everything is gonna be okay, from now and for 5-10 years letter,emm... you will get the adventages this investment. (Jangan khawatir, semua akan baik-baik saja, mulai dari sekarang dan 5-10 tahun kamu akan merasakan keuntungan dari investasi ini).

P2: Are you sure? (Apa kamu yakin?)

P1: Come on, ngapain gua ngajak lu invest ini kalau nggak ada untungnya,

P2: Tunggu lah, gua masih ragu.

P1: Hidiiih lu mah...

Terjadinya peristiwa alih kode pada data (8) ini ditandai dengan adanya dua kali peralihan ragam bahasa. Peralihan ragam bahasa pertama adalah menggunakan ragam bahasa Indonesia formal ke ragam bahasa Indonesia informal yang ditunjukkan dengan adanya kalimat Kalau tidak dimulai dari sekarang, kapan lagi?. Kemudian beralih menggunakan ragam bahasa Indonesia informal yang ditunjukkan dengan adanya kalimat Properti itu menjanjikan loh, tuh banyak kan anak-anak PJ yang invest ke properti sekarang, kata loh, tuh, kan tersebut menunjukkan ragam bahasa Indonesia informal. kemudian beralih kode kembali dari ragam bahasa Indonesia informal ke bahasa Inggris. Peralihan kode ini dimaksudkan P1 untuk meyakinkan P2 perihal investasi properti yang ditunjukkan dengan adanya kalimat Don't worry, everything is gonna be okay, from now and for 5-10 years letter,emm... you will get the adventages this investment.

\section{f) Mengubah Situasi}

Pada data (6), terjadi peristiwa alih kode intern di dalam kereta api Malabar. 
(6)P1: Ambil semua bang, pasti habis. Hehehe

P2: Pedes toh?

P1: Yoi, level dua belas.

P2:Siapin air mineral ya?

P1: frezeer nya sekalian. Hehehe.

Terjadinya peristiwa alih kode pada data (6) ini ditandai dengan adanya peralihan ragam bahasa Indonesia formal ke ragam bahasa Indonesia informal yang ditunjukkan dengan adanya kalimat Yoi, level dua belas. Kata yoi menunjukkan ragam bahasa informal. Penggunaan ragam bahasa Indonesia informal dimaksudkan untuk mengubah situasi pembicaraan memiliki sisi humor.

\section{g) Menunjukkan Sesuatu}

Pada data (9), terjadi peristiwa alih kode intern di dalam kereta api Mutiara Selatan.

(9)P1: Teh tawar hangat, Mbak.

P2: Berapa cup, Pak?

P3: Abdi nambut gunting? (Aku pinjam gunting?)

P2: Tuh aya dina sorog nu handap. (Itu ada di laci bawah)

Silahkan Pak, pesanan teh nya...

P1: Berapa, Mbak?

P2: Sepuluh ribu...

Terjadinya peristiwa alih kode intern pada data (9) ini ditandai dengan munculnya peralihan ragam bahasa Indonesia formal ke bahasa Sunda yang ditunjukkan dengan adanya kalimat Abdi nambut gunting?. Kemudian P1 beralih kode menggunakan bahasa Sunda yang ditunjukkan dengan adanya kalimat $\underline{T u h}$ aya dina sorog $n u$ handap. Penggunaan bahasa Sunda digunakan karena antara P2 dan P3 merupakan penutur bahasa Sunda. Peralihan kode ini dimaksudkan untuk menunjukkan letak suatu barang berupa gunting.

\section{h) Memberi Maaf}

Pada data (5), terjadi peristiwa alih kode intern di dalam kereta api Malabar.

(5)P1: Haduh, punten...?
P2: Ndak papa Mas, terima kasih ya.

P1:Sama-sama.

P2: Mas, tujuan mana?

Terjadinya peristiwa alih kode intern pada data (5) ini ditandai dengan munculnya peralihan bahasa dari bahasa Sunda ke ragam bahasa Indonesia yang ditunjukkan dengan adanya kalimat Haduh, punten ...? , kemudian P1 beralih kode menggunakan ragam bahasa Indonesia yang ditunjukkan dengan adanya kalimat Sama-sama,. Penggunaan ragam bahasa Indonesia oleh P2 dikarenakan P2 bukan merupakan penutur bahasa Sunda. Tuturan yang melatarbelakangi terjadinya peristiwa alih kode ini ditunjukkan dengan adanya kalimat Ndak papa Mas, terima kasih $y a$, dimaksudkan untuk memberi maaf terhadap tindakan yang tidak sengaja yang dilakukan oleh P1.

\section{i) Sekedar Bergengsi}

Pada data (8), terjadi peristiwa alih kode di dalam kereta api Mutiara Selatan.

(8) P1: Kalau tidak dimulai dari sekarang, kapan lagi?

Properti itu menjanjikan loh, tuh banyak kan anak-anak PJ yang invest ke properti sekarang.

Don't worry, everything is gonna be okay, from now and for 5-10 years letter,emm... you will get the adventages this investment. (Jangan khawatir, semua akan baik-baik saja, mulai dari sekarang dan 5-10 tahun kamu akan merasakan keuntungan dari investasi ini).

P2: Are you sure? (Apa kamu yakin?)

P1: Come on, ngapain gua ngajak lu invest ini kalau nggak ada untungnya,

P2: Tunggu lah, gua masih ragu. P1: Hidiiih lu mah...

Terjadinya peristiwa alih kode pada data (8) ini ditandai dengan munculnya peralihan bahasa dari ragam bahasa Indonesia ke bahasa Inggris yang ditunjukkan dengan adanya kalimat $\underline{\text { Kalau }}$ 
tidak dimulai dari sekarang, kapan lagi?, kemudian beralih menggunakan bahasa Inggris yang ditunjukkan dengan adanya kalimat Don't worry, everything is gonna be okay, from now and for $5-10$ years letter,emm... you will get the adventages this investment, Penggunaan bahasa Inggris dalam tuturan P1 memiliki maksud untuk sekedar bergengsi sebagai dwibahasawan. Peralihan kode pada P1 dipengaruhi oleh latarbelakang sosial dan pendidikan.

\section{3) Faktor Penyebab Terjadinya Alih Kode Terhadap Penumpang Kereta Api Jurusan Malang-Bandung.}

\section{a) Pemeran Serta (Participant)}

Pada data (8), terjadi peristiwa alih kode di dalam kereta api Mutiara Selatan.

(8)P1: Kalau tidak dimulai dari sekarang, kapan lagi?

Properti itu menjanjikan loh, tuh banyak kan anak-anak PJ yang invest ke properti sekarang.

Don't worry, everything is gonna be okay, from now and for 5-10 years letter,emm... you will get the adventages this investment. (Jangan khawatir, semua akan baik-baik saja, mulai dari sekarang dan 5-10 tahun kamu akan merasakan keuntungan dari investasi ini).

P2: Are you sure? (Apa kamu yakin?)

Terjadinya peristiwa alih kode pada data (8) ini ditandai dengan munculnya peralihan bahasa dari ragam bahasa Indonesia ke bahasa Inggris yang ditunjukkan dengan adanya kalimat Kalau tidak dimulai dari sekarang, kapan lagi?, kemudian beralih kode menggunakan bahasa Inggris yang ditunjukkan dengan adanya kalimat Don't worry, everything is gonna be okay, from now and for 5-10 years letter,emm... you will get the adventages this investment.

Penggunaan bahasa Inggris pada tuturan P1 memiliki maksud mempersuasif
P2 untuk memulai investasi properti di usia muda yang merupakan masa produktif untuk memulai investasi jangka panjang.

\section{b) Kehadiran Orang Ketiga}

Pada data (9), terjadi peristiwa alih kode di dalam kereta api Mutiara Selatan.

(9)P1: Teh tawar hangat, Mbak.

P2: Berapa cup, Pak?

P3: Abdi nambut gunting? (Aku pinjam gunting?)

P2: Tuh aya dina sorog nu handap. (Itu ada di laci bawah) Silahkan Pak, pesanan teh nya...

P1: Berapa, Mbak?

P2: Sepuluh ribu...

Terjadinya peristiwa alih kode pada data (9) ini ditandai dengan munculnya peralihan bahasa dari ragam bahasa Indonesia ke bahasa Sunda yang ditunjukkan dengan adanya kalimat Berapa cup, Pak? Kemudian P2 beralih kode menggunakan bahasa Sunda yang disebabkan adanya kehadiran orang ketiga (P3) yang ditunjukkan dengan adanya kalimat $A b d i$ nambut gunting?. Penggunaan bahasa Sunda pada tuturan P2 bermaksud menyesuaikan kode yang digunakan oleh mitra tutur karena hadirnya P3. Peralihan kode terjadi karena P2 dan P3 yang merupakan penutur bahasa Sunda.

\section{c) Topik}

Pada data (3), terjadi peristiwa alih kode di dalam kereta api Mutiara Selatan.

(3)P1: Rara. Sudah berapa hari ini, aku nggak bisa tidur.Terbayang bae terus wajah dio.

P2: Sunnahan aja.

P1: Sudah, tapi malah wajahnya berasa muncul terus.

P2: Jangan-jangan kalian bakal berjodoh.

P1: Susah sih.

Terjadinya peristiwa alih kode pada data (3) ini ditandai dengan munculnya peralihan bahasa dari ragam bahasa Indonesia ke bahasa Palembang yang 
ditunjukkan dengan adanya kalimat Rara. Sudah berapa hari ini, aku nggak bisa tidur kemudian beralih kode menggunakan bahasa Palembang yang ditunjukkan dengan adanya kalimat Terbayang bae terus wajah dio. Penggunaan bahasa Palembang dimaksudkan P1 untuk menceritakan isi perasaanya kepada P2. Peralihan kode pada tuturan P1 dilakukan dengan tujuan untuk mengubah topik pembicaraan menjadi lebih bermakna khusus tentang ungkapan perasaan P1 kepada orang yang dimaksud yaitu Rara.

\section{d) Latarbelakang Penutur}

Pada data (1), terjadi peristiwa alih kode yang terjadi di dalam kereta api Malabar.

(1)P1:...Iya maksudnya dari jam delapan sampai jam berapa?

P3:Ha, jam delapan sampai jam tiga.

P1:Tapi itu kan perlu input KRS.

P2: Yes, right, angkatan 2018 itu pokoknya....

P1: Do you have input KRS? (apakah kamu sudah input KRS?)

P2: Not yet. (Masih belum.)

Terjadinya peristiwa alih kode pada data (1) ini ditandai dengan munculnya peralihan bahasa dari bahasa Indonesia ke bahasa Inggris yang ditunjukkan dengan adanya kalimat Tapi itu kan perlu input KRS. Kemudian P1 beralih kode menggunakan bahasa Inggris yang ditunjukkan dengan adanya kalimat Do you have input KRS? Penggunaan bahasa Inggris dimaksudkan P1 untuk menyamakan kode dengan mitra tuturnya yaitu P2 yang menggunakan bahasa Inggris. yang ditunjukkan dengan adanya kalimat Yes, right, angkatan 2018 itu pokoknya. Peralihan kode ini terjadi karena dipengaruhi oleh latarbelakang pendidikan si penutur yang memiliki kemampuan dwibahasawan.

\section{PENUTUP}

Wujud tuturan yang terjadi dalam tuturan penumpang kereta api jurusan Malang-Bandung meliputi alih kode intern yaitu berupa alih kode dari bahasa Indonesia ke bahasa Jawa, Sunda, Batak, dan Palembang serta alih kode ekstern yang berupa alih kode dari bahasa Indonesia ke bahasa Inggris.

Makna tuturan alih kode penumpang kereta api jurusan Malang-Bandung, yaitu menegaskan/menjelaskan sesuatu, mengakrabkan diri,menawarkan sesuatu, memerintahkan sesuatu, meyakinkan sesuatu, mengubah situasi, menunjukkan sesuatu, memberi maaf, dan sekedar bergengsi.

Faktor penyebab terjadinya alih kode, yaitu participant, kehadiran orang ketiga, topik, dan latar belakang penutur.

\section{DAFTAR PUSTAKA}

Alwi,Hasan dkk. 2010.Tata Bahasa Baku Bahasa Indonesia. Jakarta:Pusat Bahasa dan Balai Pustaka.

Arikunto, S. 2007. Prosedur Penelitian Suatu Pendekatan Praktek. Edisi Revisi VI hal 134. Rineka Cipta: Jakarta.

Chaer, Abdul \& Agustina, Leonie. 2014.Sosiolinguistik: Perkenalan Awal.Jakarta: Rineka Cipta.

Gunarwan, Asim. 1994. "Kesantunan Negatif di Kalangan Dwibahasawan Indonesia-Jawa di Jakarta: Kajian Sosiopragmatik” dalam PELLBA 7. Jakarta: Pusat Kajian Bahasa dan Budaya Unika Atmajaya.

Kunjana. Rahardi. 2001. Sosiolinguistik: Kode dan alih kode. Jakarta: PT. Gramedia Pustaka Utama.

Kunjana. Rahardi. 2009. Sosiopragmatik. Jakarta: Penerbit Erlanga 
Jurnal Filsafat, Sains, Teknologi, dan Sosial Budaya

Volume 26, Nomor 2, Oktober 2020

Mahsun.2007. Metode Penelitian Bahasa. Jakarta: PT Raja Grafindo Persada.

Munandar Aris.2018. Alih Kode dan Campur Kode Dalam Interaksi Masyarakat Terminal Mallengkeri

Kota Makassar.core.ac.uk.Skripsi:Universit as Negeri Makassar. (diakes 10 Januari 2020)

Mustikawati Diyah Atiek.2015. Alih Kode dan Campur Kode Antara Penjual dan Pembeli (Analisis Pembelajaran Berbahasa Melalui Studi Sosiolinguistik). Jurnal Dimensi Pendidikan dan Pembelajaran 2 (2), 23-32,2016. Jurnal:umpo.ac.id. (diakses tanggal 4 Januari 2020)

Nababan,P.W.J.1984. Sosiolinguistik : Suatu Pengantar. Jakarta: Gramedia.

Nazir, Moh. 2013. Metode Penelitian. Bogor: Ghalia Indonesia.

Nurjamily, Wa Ode. 2015. Kesantunan Berbahasa Indonesia dalam Lingkungan Keluarga (Kajian Sosiopragmatik). Jurnal Humanika 15 (3), 2015. Jurnal:ojs.uho.ac.id. (diakses tanggal 10 Januari).

Poedjosoedarmo, Soepomo. 1976. Kode dan Alih Kode. Yogyakarta: Balai Penelitian Bahasa Yogyakarta. 